\title{
Whose Knowledge, Whose nature? Biodiversity, Conservation, and the Political Ecology of Social Movements
}

\author{
Arturo Escobar ${ }^{1}$

\section{Introduction: Biodiversity as a Cultural and Political Discourse}

This paper lays down the rudiments of a framework for rethinking the appropriation and conservation of biological diversity from the perspective of social movements, particularly those that have emerged recently in biodiversity-rich regions such as tropical rainforests. It is not the only, or even a privileged, framework for examining this biologically, culturally, and politically complex issue, but one that, it is argued, is useful if the claims on biodiversity by social movements are to be taken seriously. Discussions of the economic, technological, and managerial mechanisms for actualizing and distributing the benefits of biodiversity have occupied most of the attention in national and international circles. At the same time, these discussions have been accompanied by a parallel process, namely, the appearance of new social actors, including progressive NGOs in many countries and local social movements engaged in the redefinition of cultural and ethnic identities. The political strategies of these actors constitute an important intervention into what is already a highly transnationalized nature/culture field.

The framework in question is structured around the following set of propositions, developed in respective parts of the paper.

\begin{abstract}
I. Although "biodiversity" has concrete biophysical referents, it must be seen as a discursive invention of recent origin. This discourse fosters a complex network of actors, from international organizations and northern NGOs to scientists, prospectors, and local communities and social movements. This network is composed of sites with diverging biocultural perspectives and political stakes.
\end{abstract}

1. This paper was initially prepared for the Ajusco Forum on "Whose Nature?

Biodiversity, Globalization and Sustainability in Latin America and the Caribbean," held at El Colegio de México (Mexico) on November 19-21, 1997. I am grateful to Enrique Leff for his invitation to participate in this event and for his support. I am also deeply indebted to Libia Grueso, Yellen Aguilar and Carlos Rosero of the Process of Black Communities of the Pacific Coast of Colombia (PCN) for sharing with me their invaluable insights and knowledge of the PCN's political ecology discussed here. Finally, I would like to thank James Greenberg for his interest and support, and two anonymous reviewers for the journal, whose comments were very helpful in making revisions on a previous version of the paper. 
II. Through the cultural politics they enact, social movements advance a unique approach to biodiversity conservation and appropriation. This approach is couched in terms of cultural difference, territorial defense, and some measure of social and political autonomy. In subscribing to a view of biodiversity as linked to cultural and territorial defense, these social movements articulate an alternative political ecology framework.

III. When seen from this perspective, particular issues within biodiversity debates (territorial control, alternative development, intellectual property rights, genetic resources, local knowledge, and conservation itself) take on new dimensions; they can no longer be reduced to the managerial and economizing prescriptions offered by dominant views. By placing these debates in the context of the political ecology of social movements, the entire biodiversity network is transformed. Marginal sites, such as local communities and social movements, come to be seen as emergent centers of innovation and alternative worlds.

The aim of the paper is to contribute to imagining such alternative worlds. It highlights the constructions of nature and culture harbored in the political strategies that social movements articulate in their encounter with environmental destruction and biodiversity conservation.

\section{The Biodiversity Production Network}

The ferment of activity that characterizes the biodiversity field today is novel but not without historical precedents. The most clear antecedent is found in the history of "botanizing" during the ages of empire and exploration, when "overseas collectors made up the most extensive scientific network in the world" (D. Mackay 1996: 39). During this time, plant collecting was intimately linked to questions of culture, empire and economy. Lessons from this past experience can be drawn by examining today"s biodiversity debates in much the same way as historians of science and empire are looking at their historical cases (D. Miller and P.H. Reill 1996). Concepts that were initially introduced in the field of science and technology studies (STS) can be used to examine the incredibly complex field of biodiversity today. I start by outlining a discursive approach to biodiversity before introducing the STS concept of "network."

This approach suggests that it is possible to examine "biodiversity" not as a true object that science progressively uncovers, but as an historically produced discourse. This discourse is a response to the problematization of survival motivated by the loss of biological diversity. As Wilson put it, "biological diversity is the key to the maintenance of the world as we know it" (1993:19). It was thus that biodiversity irrupted in the world theater of science and development in the late 1980s. The textual origins of this emergence can be identified with precision: the publication of Global Biodiversity Strategy (WRI/ IUCN/UNEP 1992); and the Convention on Biological Diversity (CBD), signed at the Earth Summit in Rio de Janeiro in 1992. Subsequent texts and elaborations, from the plethora of UN and NGO meeting reports to Global Environment Facility (GEF) project descriptions, exist within the confines of this discourse.

But does "biodiversity" exist? Is there a discrete reality of "biodiversity" different from the infinity of living beings, including plants, animals, microorganisms, homo sapiens, and their interactions, attraction and repulsion, co-creations and destructions? Foucault (1980) suggested that "sex" does not exist, but that it is an artificial construct required for the deployment of sexuality as an historical discourse. Is biodiversity 
similarly the construct around which a complex discourse of nature is being deployed? If this is so, then, as in the case of sexuality, the biodiversity discourse would anchor an entire apparatus for the dispersion of new truths throughout vast social domains.

From a biological standpoint, one could say that biodiversity is the effect of all this natural complexity, and that it could thus be specified in functional and structural terms. In fact, the current scientific approach to biodiversity is geared not toward "theorizing biodiversity" per set but towards assessing the significance of biodiversity loss to ecosystem functioning, and to ascertaining the relation between biodiversity and the "services" ecosystems provide. ${ }^{2}$ Established definitions of biodiversity do not create a new object of study that is outside of the existing definitions in biology and ecology. ${ }^{3}$ Rather, "biodiversity" is the response given to a concrete situation that is certainly preoccupying but which goes well beyond the scientific domain. As critical studies of science have shown, the act of naming a new reality is never innocent. What views of the world does this naming shelter and propagate? Why has this new way of naming been invented at the end of a century that has seen untold levels of ecological destruction?

From a discursive perspective, then, biodiversity does not exist in an absolute sense. Rather, it anchors a discourse that articulates a new relation between nature and society in global contexts of science, cultures, and economies. As a scientific discourse, biodiversity can be seen as a prime instance of the coproduction of technoscience and society that STS scholars analyze in terms of networks. ${ }^{4}$ Technoscientific networks are seen as chains of sites characterized by a set of heterogeneous parameters, practices and actors. Each actor's identity is affected by, and affects, the network. Intervention in the network is done by means of models (e.g., of ecosystems, conservation strategies); theories (e.g., of development, restoration); objects (from plants and genes to various technologies); actors (prospectors, taxonomists, planners, experts); strategies (resource management, intellectual property rights); etc. These interventions effect and motivate translations, transfers, travels, mediations, appropriations and subversions throughout the network. Although local practices might have extra-local origins and consequences, each site can be

2. The SCOPE (Scientific Committee on Problems of the Environment) Program on Ecosystem Functioning of Biodiversity, and the United Nations Environment Program's Global Biodiversity Assessment Program follow this approach. See SCOPE's technical volumes, particularly H.A. Mooney et al. (1995); and the useful review of the project in Baskin (1997).

3. Article 2 of the Convention on Biological Diversity, for instance, provides the following definition: “' 'Biological diversity' means the variability among living organisms from all sources including, inter alia, terrestrial, marine and other aquatic ecosystems and the ecological complexes of which they are part; this includes diversity within species, between species and of ecosystems." This definition has been further refined by the World Resources Institute (WRI) as comprising genetic diversity, the variation between individuals and populations within a species, and species and ecosystems diversity, to which some also add functional diversity (WRI 1994: 147). 4. In its "classical" formulation, the actor network theory was proposed by Callon (1986) and Latour $(1983,1993)$ as a methodology to study the coproduction of technoscience and society. It has been refined and transformed since by anthropologists of science and technology such as Rayna Rapp, Emily Martin, Deborah Heath and Donna Haraway. For an introduction to this field, see Hess (1997); on networks, see Escobar (1998). 
the basis of its own network. As we shall see, the work of activists of the Colombian Pacific region originates a network of its own which encompasses local communities and ecosystems.

The biodiversity network initially originated in the late 1980s and early 1990s out of conservation biology, where "the idea of biodiversity" (D. Takacs 1996) first flourished. It soon articulated a master narrative of biological crisis ("if you want to save the planet, this is what you must do, and here are the knowledge and resources to do it") launched globally at what has been called the first rite of passage to the "transnation state," the 1992 Rio Summit (G.L. Ribeiro 1997). According to actor-network theory, the biodiversity narrative created obligatory passage points for the construction of particular discourses. This process translates the complexity of the world into simple narratives of threats and possible solutions. The aim was to create a stable network for the movement of objects, resources, knowledge, and materials. This simplified construction was perhaps most effectively summarized in Janzen's moto about biodiversity: “you've got to know it to use it, and you've got to use it to save it" (1992; D. Janzen and H. Hallwachs 1993). In a few years, an entire network was established that amounted to what Brush (1998) has aptly called a tremendous "invasion into the public domain." Yet the biodiversity network has not resulted in a hegemonic and stable construction as in other instances of technoscience. As we shall see, countersimplifications and alternative discourses produced by subaltern actors also circulate actively in the network with important effects.

The biodiversity discourse has thus resulted in an increasingly vast institutional apparatus that systematically organizes the production of forms of knowledge and types of power, linking one to the other through concrete strategies and programs. International institutions, Northern NGOs, botanical gardens, universities and research institutes in the first and third worlds, pharmaceutical companies, and the great variety of experts located in each of these sites occupy dominant sites in the network. As they circulate through the network, truths are transformed and re-inscribed into other knowledge-power constellations. They are alternatively resisted, subverted, or recreated to serve other ends, for instance, by social movements, that become, themselves, the sites of important counterdiscourses. The network is continuously transformed in light of the translations, transfers, and mediations that occur among and across sites. Such sites are more than "local" places strictly speaking, and are defined by processes that take place within the network, where the boundaries of technoscience and other domains are never stable.

At the risk of oversimplifying, it is possible to differentiate among four major positions produced by the biodiversity network to this date (see A. Escobar 1997a for a more exhaustive analysis). It must be stressed that each of these positions are themselves heterogeneous and diverse, and that the entire biodiversity field is extremely dynamic and rapidly changing. At the level of discursive regularities, however, the four positions can be mapped as relatively distinct discursive formations, even if often overlapping:

\section{Resource Management: Globalocentric perspective.}

This is the view of biodiversity produced by dominant institutions, particularly the World Bank and the main northern environmental NGOs (e.g., World Conservation Union, World Resources Institute, and World Wildlife Fund), and supported by G-7 countries. It is based in a particular representation of the "threats to biodiversity" that emphasizes loss of habitats, species introduction in alien habitats, and fragmentation due to habitat reduction, rather than underlying causes; it offers a set of prescriptions for the 
conservation and sustainable use of resources at the international, national, and local levels; and it suggests appropriate mechanisms for biodiversity management, including scientific research, in-situ and ex-situ conservation, national biodiversity planning, and the establishment of appropriate mechanisms for compensation and economic use of biodiversity resources, chiefly through intellectual property rights. This dominant discourse is actively being promoted from a variety of sites and through manifold academic, institutional, managerial, and political practices. It originates in dominant views of science, capital, and management (see WRI/IUCN/UNEP 1992; WRI 1994: 149151).

A central place in the dissemination (and contestation, below) of this perspective is occupied by the activities surrounding the Convention of Biological Diversity, including the follow-up Conferences of the Parties with their respective scientific and institutional agendas, subgroups, policies, and mechanisms. The CBD underlies, for most purposes, the basic architecture of the biodiversity network. As the information kit for the fourth meeting of the Conference of the Parties (COP 4), held in Bratislava on May 4-15, 1998 states:

Just six years after its adoption at the 1992 Rio Earth Summit, the Convention of Biological Diversity (CBD) is starting to transform the international community's approach to biodiversity. This progress has been driven by the Convention's inherent strengths and near-universal membership (over 170 parties), a comprehensive scientific-driven mandate, international financial support for national projects, worldclass scientific and technological advice, and political involvement of government ministers (Downloaded from the CBD web page). ${ }^{5}$

An ethnography of the CBD and related network activities remains to be done, even if the most important institutional and knowledge/power practices can be easily identified. Among these practices are: national, regional and international meetings leading up to COP meetings; the establishment of particular groups within the CBD structure (such as the Subsidiary Body for Scientific, Technical and Technological Advise [SBSTTA] and the ad-hoc Working Group of Experts on Biological Diversity); and the practice of national delegations and reports. An ethnographic perspective on the CBD-centered network would also have to examine the chief mechanisms for the construction of concepts and objects of study, including the progressive specification and inclusion of new knowledge and policy areas (e.g., forest biodiversity, agricultural biodiversity, marine and sea biodiversity, biosafety); the proliferation of issues (genetic resources, benefit sharing, biotechnology, impact assessment, indigenous and traditional knowledge, in-situ conservation, technology transfer, etc.); and the criteria of expertise and role of scientific knowledge. Finally, a key process to be examined from such an ethnograhic perspective is the growing participation of NGOs and social movements.

5. There are many internet sources for following biodiversity debates in general and the CBD in particular. Among the most useful and visible are: EcoNet (run by the Institute for Global Communications, San Francisco); and the Earth Negotiations Bulletin (enb@igc.apc.org), run by the International Institute for Sustainable Development, which includes detailed reports on the various COP meetings to date. The many smaller international and national networks and publications on biodiversity are too numerous to list here. 
It is through this set of practices that the dominant biodiversity discursive formation is crafted, implemented, and eventually contested. This contestation takes place at many levels. At COP 4, for instance, indigenous representatives reached a consensus on the implementation of Article $8 \mathrm{j}$ of the CBD, which calls for the respect and maintenance of local knowledge practices. This consensus calls for the creation of a permanent working group with full participation of indigenous peoples as the only way in which the defense of their knowledge and resources can be advanced within the CBD. Instances such as this have motivated many observers to highlight the role of the CBD as a space of resistance against the "green developmentalism" that has engulfed the Convention and the global biodiversity debates (K. McAfee 1997).

The discourse of biodiversity as resource management is linked to three other discourses: conservation science (and related fields), sustainable development, and benefits sharing either through intellectual property rights or through other mechanisms. Although increasing attention is paid to traditional knowledge, the conventional scientific disciplines continue to dominate the overall approach. For instance, SBSTTA's second meeting of 1996 included technical issues such as monitoring and assessment of biodiversity, taxonomy approaches, economic valuation, genetic resources, biosafety, and various forms of biodiversity (marine and coastal, terrestrial, agricultural). All of these topics fall within the realm of expertise of modern science. The sustainable development conception is never problematized, even if critics have pointed with growing eloquence at the impossibility of harmonizing the needs of economy and environment within the existing frameworks and institutions of the economy (R. Norgaard 1995; A. Escobar 1995). Finally, the intellectual property rights discourse dominates the biodiversity debates on benefit sharing and compensation. This is clearly a neoliberal imposition of the industrialized countries (particularly the US) rather than an option democratically agreed upon.

A special mention needs to be made of the related practices of prospecting and ethnobioprospecting. Under the guise of "gene hunting," bioprospecting played an important, and somewhat unfortunate, role in the initial years of the discourse (WRI 1993), giving rise to hopes ("gene rush") or fears (biopiracy) that were not entirely substantiated nor easily assuaged. Much has been learned since, and recent works show a much greater degree of conceptual and political sophistication (e.g., S. Brush and D. Stabinski 1996; M. Balick, E. Elisabetsky and S. Laird 1996). Many observers believe that some form of bioprospecting will remain important for at least a decade. Tied to the patenting of life forms, bioprospecting can indeed result in very troubling developments, including the loss for small farmers and indigenous peoples of rights to their own plants and knowledge (GRAIN 1998). Most prospecting activities today are conceived in relatively conventional terms. Nevertheless, a number of interesting proposals for collaboration between prospectors and communities have emerged. Shaman Pharmaceutical, for instance, has developed a suggestive protocol for providing long-term reciprocal and short-term benefits to communities while contributing to the preservation of local ecosystems and cultural knowledge (S. King,T. Carlson and K. Moran 1996; K. Moran 1997). The long-term fate and effect of these approaches is far from clear, and they do not address the contradictions of creating this type of hybrid nature (hybridizing capitalist and non-capitalist nature, see A. Escobar 1999) that arise in contrasting ways of seeing and practicing nature (S. Gudeman 1996). Yet the fact is that this encounter of economic, ecological and cultural rationalities will continue. This issue has to be broached 
in earnest, with the aim of strengthening the autonomy of local communities over their knowledge and resources.

\section{Sovereignty: Third World National Perspectives.}

Although there is great variation in the positions adopted by national governments in the Third World, it can be said that there is a Third World national perspective that, without questioning in any fundamental way the globalocentric discourse, nevertheless seeks to negotiate the terms of biodiversity treaties and strategies. The issue of genetic resources has rekindled the interest of Third World governments in these negotiations. Unresolved issues such as in-situ conservation and access to ex-situ collections; sovereignty of access to genetic resources; ecological debt; and the transfer of financial and technical resources to the Third World are important agenda items in these negotiations, sometimes collectively advanced by regional groups, such as the Andean Pact countries. Some countries have taken a leading role in pushing for certain items (e.g., a moratorium on bioprospecting promoted by a few countries at COP-3). Others have opposed policies favored by the industrialized nations (for instance, certain aspects of intellectual property rights); and still others have called on industrialized countries for their unwillingness to negotiate key issues such as technology transfer and financial resources for conservation.

The position of national governments is key in international fora such as the CBD. It is also crucial for subnational NGOs and social movements (see below). An ethnographic account of this second network space would examine the articulations of national, international, and subnational practices; the contestations, travels, and mediations that take place among actors at each step; and their effects on concrete conservation policies, strategies, and programs. Under CBD mandate, national governments have to pursue biodiversity planning, for which blueprints have already been established (WRI 1995). These blueprints and plans are conceived in very conventional terms of development planning, and can be analyzed ethnographically as instances of the organization of knowledge and power (J. Ferguson 1990; A. Escobar 1995). The resulting policies of conservation and sustainable development will depend on the struggle and genotiation over models of nature and social practice among the groups involved. As we will see, the ethnography of the Colombian case suggests that social movements can affect considerably the outcome of national conservation policies.

\section{Biodemocracy: Progressive Southern NGO Perspective.}

For an increasing number of southern NGOs, the dominant, globalocentric perspective amounts to a form of bioimperialism. By reinterpreting the "threats to biodiversity" (putting emphasis instead on habitat destruction by megadevelopment projects, the monocultures of mind and agriculture promoted by capital and reductionist science, and the consumption habits of the North fostered by economistic models), biodemocracy advocates shift the attention from South to North as the source of the diversity crisis. At the same time, they suggest a radical redefinition of production and productivity away from the logic of uniformity and toward the logic of diversity. They see this as the historical heritage of Third World communities. This strategic use of the holism of ecology is convincingly presented as more enlightened science. The proposal for biodemocracy that ensues is articulated around a series of requirements that include: local 
control of natural resources; suspension of megadevelopment projects and of subsidies to diversity-destroying capital activities; support for practices based on the logic of diversity; redefinition of productivity and efficiency to reflect this logic; and recognition of the cultural basis of biological diversity. ${ }^{6}$

In addition, these critics are adamantly opposed to both biotechnology as a tool to maintain diversity and to the adoption of intellectual property rights as the mechanism for the protection of local knowledge and resources. Instead, they advocate for forms of collective rights that recognize the intrinsic value and the shared character of knowledge and resources (Third World Network and Research Foundation 1994). In a fundamental way, this view thus contests the most cherished constructs of modernity, such as positivist science, the market, and individual property. As such, it constitutes an important critique of globalocentric perspectives. Ethnographically, attention should be paid to the constitution of subnetworks at national and transnational levels; the circulation of discourses, activists and progressive scholars through these networks and through the principal biodiversity network sites; the reception and productivity of these discourses; and the relation between the actors in this discursive formation and local social movements. More ethnographic research is needed on how these organizations articulate their visions and issues (e.g., on genetic resources, patenting of life forms, indigenous knowledge) in terms of science, gender, nature, culture and politics. These organizational networks are also a prime example of the emergent set of transnational practices and identities that link virtual and place-based modes of activism and that enact a cybercultural politics which is increasingly, and paradoxically, important for the defense of places (G.L. Robeiro 1998; A. Escobar 1998).

\section{Cultural Autonomy: Social Movements Perspective.}

This perspective will be discussed at length in the rest of the paper. The social movements considered here are those that explicitly construct a political strategy for the defense of territory, culture, and identity linked to particular places and territories. These movements enact a cultural politics that is mediated by ecological considerations. While having many points in common with the southern NGO perspective, they are distinct conceptually and politically and occupy a different position in the biodiversity network.

6. The Malaysian-based Third World Network and Vandana Shiva'sResearch Foundation for Science, Technology, and Natural Resource Policy in India have taken a leading role in the denunciation of bioimperialism and the articulation of biodemocracy. They are joinded in this effort by a number of NGOs in Latin America, Africa, and a few in North America and Europe. There are progressive NGOs in almost every country in Latin America with connections to this perspective (such as Acción Ecológica in Ecuador and Grupo Semillas in Colombia). The most prominent and active in North America and Europe include the Rainforest Action Network (RAN) in San Francisco; the Canadian Rural Advancement Foundation International (RAFI); and the Barcelona-based Genetic Resources Action International (GRAIN). Together, all of these NGOs enact through their practice a lose network of their own. On this perspecive, see especially the works of Vandana Shiva (1993, 1884, 1997; Shiva et al. 1991); the Third World Network magazine, Resurgence; RAFI's communiqués and Occasional Paper series (www.rafi.ca); and GRAIN's newsletter, Seedlings. See also Escobar (1997a). 
Aware that "biodiversity" is a hegemonic construct, activists of these movements acknowledge that this discourse nevertheless opens up a space for the construction of culturally based forms of development that could counteract more ethnocentric and extractivist tendencies. Theirs is the defense of an entire life project, not only of "resources" or biodiversity.

The emergence of social movements that explicitly appeal to biodiversity discourses as part of their strategy is recent. In many cases, the concern with biodiversity has followed from broader struggles for territorial control. In Latin America, a number of valuable experiences have taken place in this regard, chiefly in conjunction with the demarcation of collective territories in countries such as Ecuador, Peru, Colombia, Bolivia and Brazil. These experiences are yet to be examined ethnographically and comparatively in a thorough manner. ${ }^{7}$

There is a final issue to be mentioned briefly before proceeding to the analysis of the Colombian case. It is clear from the four discourses on biodiversity just outlined that there is a fundamental asymmetry in biodiversity texts between modern science and economics and local knowledge and practices of nature. Although some attention is now given to local knowledge in biodiversity debates (particularly around the discussion and implementation of article $8 \mathrm{j}$ of the CBD), this attention is insufficient and often misguided to the extent that local knowledge is rarely understood in its own terms or it is refunctionalized to serve the interest of Western-style conservation. Beyond the political economy argument of capital's predation of local ecologies and knowledge (V. Shiva 1997), there are basic cultural and epistemological considerations at play, particularly the extent to which local and modern forms of knowledge entail different ways of apprehending the world and of appropriating the natural (E. Leff 1997). There is little doubt today that this is the case if one looks at the increasingly detailed literature on local cultural models of nature.

Anthropologists, geographers, and political ecologists are demonstrating with increasingly eloquence that many rural communities in the Third World "construct" nature in strikingly different ways from the prevalent modern forms. They signify, and thus use, their natural environment in quite specific ways. Ethnographic studies unveil a coherent set of practices of thinking about, relating to, and using the biological. The project of documenting cultural models of nature was formulated some time ago (M. Strathern 1980) and has achieved a remarkable level ofsophistication in recent years (P. Descola and G. Pálsson 1996; S. Gudeman and A. Rivera 1990). There is, of course, no unified view of what constitutes a cultural model of nature, or how these models operate cognitively and socially. To analyze this vast literature is beyond the scope of this paper. Suffice it to say that one of the most commonly accepted notions is that many local models do not rely on a nature-society dichotomy. Unlike modern constructions, with their strict separation between biophysical, human, and supernatural worlds, local models in many non-Western contexts are often predicated on links of continuity between the three spheres and embedded in social relations that cannot be reduced to modern, capitalist terms.

7. The work of Soren Hvalkof with the project of collective titling of the Asháninka of the Gran Pajonal of the Peruvian Amazon is one of the few and most exciting instances of long-term ethnographic involvement with indigenous communities around culture/ territory issues. See Hvalkof (1998). 
Similarly, there seems to be a certain convergence in recent anthropological approaches in treating local knowledge as "a practical, situated activity, constituted by a past, but changing, history of practices" (M. Hobart 1993: 17). This assumes that knowledge works more through a body of practices than by relying on a system of shared, context-free knowledge. This practice-oriented view of local knowledge has its origin in a variety of theoretical positions (from Heidegger to Bourdieu and Giddens). A related trend emphasizes the embodied aspects of local knowledge. For Ingold (1995, 1996), our knowledge of the world can be described as a process of enskillment in the context of our practical engagement with the environment. Humans, in this view, are embedded in nature and engaged in situated, practical acts. For Richards (1993), local agricultural knowledge must be seen as a set of time and context-specific improvisational capacities rather than as constituting a coherent "indigenous knowledge system," as earlier literature suggested. In this performative view of local knowledge, it is proper to speak of embodied capacities in the performance of tasks in social contexts shaped by particular cultural logics. These welcome trends, of course, do not solve all the questions regarding the nature and modes of operation of local knowledge, and many open questions remain that cannot be reviewed here (see Escobar 1999). Yet it is important to signal that they might provide a broader framework to which discussions of biodiversity conservation and related issues, such as intellectual property rights, can be referred. ${ }^{8}$

This task is yet to be done. Ethnographically, the focus should be on documenting for diverse groups the ensembles of meanings-uses that characterize their engagement with the natural world. From a multiplicity of cultural models so described, we can posit a number of questions: Is it possible to launch a defense of local models of nature within the scope of biodiversity appropriation and conservation debates? In what ways would current concepts of biodiversity and local knowledge have to be transformed to make this reorientation possible? Finally, which social actors could more pertinently advance such a project?

These questions are being actively explored in two separate but increasingly interrelated domains: political ecology theory, particularly through the attempt at articulating an alternative ecological rationality (E. Leff 1995a); and social movements in biodiversity-rich regions. Whereas the former aims at developing a new paradigm of production that incorporates, for any given ecosystem and social group, cultural, ecological, and technoeconomic factors into a strategy that is ecologically and culturally sustainable, the latter attempt to construct an alternative view of development and social practice through a self-conscious and localized political strategy. Both projects have much

8. Which "local models" are different and to what extent do they enable practices that are environmentally sustainable is an empirical question. Is it necessary to say that not all local practices of nature are environmentally benign, and that not all social relations that articulate them are non exploitative?. Dahl has best summarized this point: "All people of necessity maintain ideas about, and of necessity act on, their natural environment. This does not necessarily mean that those who live as direct producers have great systematic insights, although on the whole subsistence producers have detailed knowledge about the working of many small aspects of their biological environment. Much of this knowledge has from experience proved to be true and efficient, some is misconceived and counterproductive, and some is incorrect but still functions well enough" (1993: 6). For a critique of "the myth of primitive environmental wisdom," see Milton (1996). 
to contribute to each other, as will be suggested in the last part of the paper. The rest of the paper examines how social movements are facing the biodiversity/sustainability questions from the perspective of culture and politics by focusing on one particular example, the social movement of black communities of the Pacific rainforest region of Colombia.

\section{Ethnicity, Territory, and Politics: Social Movements and the Biodiversity Question}

Since the end of the 1980s, the Pacific rainforest region of Colombia has been undergoing an unprecedented historical process: the emergence of collective ethnic identities and their strategic positioning in culture-territory relations. This process is taking place at a complex national and international conjuncture. At the national level, this conjuncture includes the neoliberal opening of the economy to world markets after 1990 and its integration into the Pacific Basin economies; and a substantial reform of the national constitution in 1991 that, among other things, granted black communities of the Pacific region collective rights to the territories they have traditionally occupied. Internationally, tropical rainforest areas such as the Pacific region have acquired a certain specificity in light of the fact that they are seen as housing the majority of the biological diversity of the planet.

The Pacific Coast region of Colombia covers a vast area (about 70,000 $\mathrm{km}^{2}$ ) stretching from Panama to Ecuador and from the westernmost chain of the Andes to the ocean. It is a unique rainforest region, one of the world's most biodiverse in scientific terms. About 60 per cent of the region's 900,000 inhabitants (800,000 Afro-Colombians, about 50,000 Embera, Waunana and other indigenous people, and mestizo colonists) live in the few larger cities and towns; the rest inhabit the margins of the more than 240 rivers, most of which flow from the Andes towards the ocean. Black and indigenous peoples have maintained distinct material and cultural practices, such as multiple subsistence and economic activities involving agriculture, fishing, hunting and gathering, and small-scale gold mining and timber collecting. They are characterized by extended families and matrilocal social relations; strong oral traditions and religious practices; and particular forms of knowledge and use of the diverse forest ecosystems. ${ }^{9}$ What is important to emphasize is the continued existence of significantly different cultures in a region that is finally attracting national and international attention. This attention is reversing the region's biological and cultural invisibility of even a decade ago.

The emergence of collective ethnic identities in the Colombian Pacific and similar regions thus reflects a double historical movement: the irruption of the biological as a global problem, on the one hand; and the irruption of the cultural and the ethnic, on the other, as it is recognized by the new Colombian constitution in its desire to construct a pluriethnic and multicultural society. To what extent does the emergence of these unprecedented identities come to constitute a new context for biodiversity discussions within the country? Is it possible to articulate an alternative view of biodiversity

9. The number and quality of studies of black cultures of the Pacific region (which includes communities in Colombia and Ecuador) has increased in recent years. For an introduction to the literature, see the works by Friedemann and Arocha (1984); Whitten (1986); Leyva 1993; Aprile-Gniset (1993); Restrepo and del Valle (1996); Escobar and Pedrosa (1996). Colombian black movements are examined in Wade (1995). 
conservation from the perspective of the aims and needs of the movements? It is perhaps too soon to argue categorically that biodiversity discourses can be reconceived from the space carved out by social movements. Nevertheless, the Colombian experience suggests paths to this rethinking. Let us see how.

Social movements theorists have recently turned their attention to the notion of cultural politics. Cultural politics is the process enacted when sets of social actors shaped by, and embodying, different cultural meanings and practices come into conflict with each other. This definition of cultural politics assumes that meanings and practices can be the source of processes that must be accepted as political. This is rarely seen as such because of entrenched definitions of the political. This is particularly the case with those practices theorized as marginal, oppositional, residual, emergent, alternative, dissident, and the like, all of them conceived in relation to a given dominant cultural order. Culture is political because meanings are constitutive of processes that, implicitly or explicitly, seek to redefine social power. When movements deploy alternative conceptions of woman, nature, development, economy, democracy, or citizenship that unsettle dominant cultural meanings, they enact a cultural politics. Cultural politics are the result of discursive articulations originating in existing cultural practices. These processes are never pure and always hybrid yet showing significant contrasts in relation to dominant cultures. ${ }^{10}$

These dynamics can be said to have been at play in the Colombian Pacific region since 1990, resulting in the emergence of important black and indigenous movements. ${ }^{11}$ Such movements have progressively come to tackle ecological questions. Since 1993, the Proceso de Comunidades Negras, PCN (Process of Black Communities, a network of more than 140 local organizations), has assumed a leading role in the struggle for the constitutional rights granted to black communities and the defense of their territories. Emphasis is given by the PCN to the social control of the territory as a precondition for the survival, recreation, and strengthening of culture. In the river communities, activists' efforts have been geared towards advancing a pedagogical process with and within the communities on the meaning of the new constitution; debating the fundamental concepts of territory, development, traditional production practices, and use of natural resources; and strengthening the organizational capacity of the communities. This sustained effort served to lay down the basis, during the 1991-93 period, for the elaboration of a proposal

10. This view of cultural politics is based on Alvarez, Dagnino and Escobar (1998). This volume elaborates the notion of cultural politics by examining the link between culture and politics established by a range of Latin American social movements, including the social movement of black communities from the PacificCoast. Of course, social movements of the right also enact a cultural politics in the defense of conservative lifeworlds. I am interested in this paper in social movements that enact a cultural politics linked to the defense of nature and culture.

11. This brief presentation of the social movement of black communities is taken from a much longer text, Grueso, Rosero and Escobar (1998); see also Escobar (1997b). It is based on on-going ethnographic research with movement activists that I have been conducting since 1993. It should be made clear that the social movement discussed here (PCN's ethnocultural proposal) is largely restricted to the central-southern part of the Pacific region. 
for the law of cultural and territorial rights called for by the 1991 constitution (Ley 70, approved in 1993), and to firm up a series of politico-organizational principles. ${ }^{12}$

The collective discussion of the proposal for Ley 70 was a decisive space for the development of the movement. This process was advanced at two levels, one centered on the daily life and practices of the black river communities, the other on an ideological and political reflection by the activists. The first level was advanced under the rubric of what was referred to as "the logic of the river;" it relied on a broad participation of local people in the articulation of their own rights, aspirations and dreams. The second level, although having the rivers and their settlements as referent, sought to transcend the rural domain to raise the question of black people as an ethnic group beyond what could be granted by the law. This level saw a rearticulation of the notions of territory, development, and the social relations of black communities with the rest of the country. Despite internal differences and manipulation of the process by black politicians linked to the traditional parties, social movement organizations were able to exert considerable influence on the drafting of the law negotiated with the government.

The movement has been growing in conceptual and political sophistication. The Third National Conference of Black Communities convened in September of 1993 in the predominantly black town of Puerto Tejada, south of Cali, in the Norte del Cauca region. It proposed the movement's goal as "the consolidation of a social movement of black communities for the reconstruction and affirmation of cultural identity," leading to an autonomous organizing strategy "for the achievement of cultural, social, economic, political, and territorial rights and for the defense of natural resources and the environment." One of the central features of the Conference was the adoption of a set of politico-organizational principles formulated out of the practice, lifeworld vision, and desires of the black communities. These principles, concerning the key issues of identity, territory, autonomy, and development, are: (1) The reaffirmation of identity (the right to being black), which identifies culture and identity as organizing axes of both daily life and political practice; (2) The right to the territory (as the space for being), which conceives of the territory as a necessary condition for the recreation and development of a black cultural vision, and as a habitat where black people develop their being in/with nature; (3) Autonomy (the right to the exercise of being/identity), particularly in the political realm, but with the aspiration of certain degree of social and economic autonomy; (4) The right to constructing an autonomous perspective of the future, particularly an autonomous vision

12. Ley 70 is composed of 68 articles distributed among eight chapters. Besides recognizing collective ownership of the territory, Ley 70 recognizes Colombian blacks as an ethnic group with rights to their identity and culturally appropriate education, and requires the state to develop social and economic policies in accordance with black culture. Similarly, development strategies for black river communities must respond to black culture and community aspirations and the preservation of ecosystems. Ley 70 defined the black community as "the ensemble of families of Afro-Colombian descent possessing their own culture, sharing a history, and practicing their own traditions and customs within the rural-town relationship, who exhibit and maintain a consciousness of identity that sets them apart from other ethnic groups." Although this definition has been criticized for being essentialist and modelled after the indigenous experience, the recognition of ethnic rights for black people is unprecedented and important. 
of development based on black culture. A fifth principle included a declaration of solidarity with the struggles for rights of black people throughout the world.

This declaration of principles already suggested a particular reading of the socioeconomic and political situation of the Pacific Coast region as a strategic ethnic and ecological unit, with the concomitant emphasis placed on cultural difference and the defense of the territory. It underlies an ethnocultural approach based on the reconstruction of cultural difference as a means to lessening ecological, socioeconomic, and political forms of domination. For the ethnocultural process, the movement needs to be built on the basis of broad demands for territory, identity, autonomy, and the right to its own vision of development and the future. Similarly, ethnocultural activists espouse a view of blackness that goes well beyond issues of skin color and the racial aspects of identity.

The social movement of black communities is embarked on a process of collective identity construction that bears similarities with that of Caribbean and Afro-British identities analyzed by Hall. For Hall (1990), ethnic identity construction is characterized by a certain doubleness: on the one hand, identity is thought of as rooted in shared cultural practices, a collective self of sorts; this conception of identity has played an important role in anticolonial struggles and involves an imaginative rediscovery of culture that lends coherence to the experience of dispersal and oppression. On the other hand, identity is seen in terms of the differences created by history; this aspect of identity construction emphasizes becoming rather than being, positioning rather than essence, and discontinuity as well as continuities at the cultural level.

This doubleness of identity can be seen at play in the ethnocultural approach of the Pacific black movement. For the activists, the defense of certain cultural practices of the river communities is a strategic move to the extent that they are seen as embodying not only resistance to capitalism and modernity but elements for alternative ecological rationalities. Although often couched in culturalist language, this defense is not essentializing to the extent that it responds to the challenges faced by the communities and the possibilities presented by a cautious opening towards forms of modernity such as biodiversity conservation and alternative development. Identity is thus seen in both ways: as anchored in "traditional" practices and forms of knowledge; and as an always changing project of cultural and political construction. In this way, the movement builds upon the submerged networks of cultural practices and meanings of the river communities and their active construction of lifeworlds (A. Melucci 1989), but take these networks as the basis for a political conception of identity that has much more to do with the encounter with modernity (state, capital, science, biodiversity) than with timeless and bounded identities.

Gender, as an important aspect of identity construction, is also progressively becoming a salient aspect in the agenda of ethnocultural organizations. Although it is still given insufficient attention, that many of the top leaders and activists of the movement are women committed to the ethnocultural approach is acting as a catalyst for the articulation of gender issues. This possibility was already felt in 1994, when the need to embrace gender as an integral part of the movement, as opposed to promoting the creation of separate women's organizations, was recognized. ${ }^{13}$ The organization of black women is beginning to overflow the boundaries of the movement and to take on a dynamic of its own. In 1992, the first meeting of black women of the Pacific Coast attracted over 500 participants; a network of black women organizations already exists and is gaining visibility in various domains of activity, particularly since 1995 (J. Rojas 1996); discourses of gender and biodiversity are also slowly emerging (J. Camacho 1996). Although most women organizing efforts are still couched in conventional "women in 
development" terms (B.R. Lozano 1996), the number of activists committed to a simultaneous gender and ethnic mobilization is increasing (K. Asher 1998).

To what extent does the social movements of black communities just described represent an alternative proposal for biodiversity conservation? In the following section, the movement's particular views on the subject are analyzed. As we shall see, through their encounter with instances of environmental conflict and initiatives, movement activists are crafting an entire political ecology that provides important elements for a redefinition of biodiversity appropriation and conservation.

\section{Cultural Politics, Biodiversity, and the Political Ecology of Social Movements}

Because of its rich natural resources, the Pacific Coast region of Colombia is currently besieged by both the national and international development establishments. The insertion of black and indigenous groups in national and international discussions about biodiversity conservation, genetic resources, and the control and management of natural resources is recent but of growing importance. From the time of the new constitution and Ley 70, when biodiversity was barely spoken about in the region, to the late 1990s, a significant terrain has been covered. One of the most important factors in this regard has been the intensive and active engagement by river communities and PCN activists with the Pacific Biodiversity Conservation Project (Proyecto Biopacífico, $\mathrm{PBP}^{14}$ ). Of growing importance also is the incipient but increasing transnationalization of the movement (activists travelling to South America, Europe and the US and participating in meetings such as COP-3 in Buenos Aires [1996], the People's Global Action against Free Trade in Geneva [1997 and 1998]; and the UN Working Group on Indigenous Populations [1998]). At the same time, PCN activists have run for local elections; continued to organize locally and regionally; sought funding for territorial demarcation; and participated in the intense negotiations over the future of the PBP(1996-1998). In the midst of this, they have seen an escalation of violence in the region, some of it directed explicitly against activists and communities to discourage them from pressing for territorial demands.

13. See the day-long interview conducted by Arturo Escobar and co-researchers with leaders of the movement, where the question of gender occupied a prominent place, mostly as it was advanced by Libia Grueso, Leyla Arroyo, and other women activists. The interview took place in Buenaventura on January 3, 1994 (Escobar and Pedrosa 1996, Chapter 10).

14. This is the Proyecto Biopacífico (PBP) for biodiversity conservation (see GEF/PNUD 1993), conceived as a Global Environment Facility (GEF) program and funded by the Swiss government and the United Nations Development Program (UNDP). As a result of black mobilization and Ley 70, the project has allowed a certain degree of participation by black organizations and accepted the latter as one of its most important interlocutors. Its initial three-year budget, however (U.S. \$ 9 million) was ridiculously low compared to the budget of the large-scale development plan, Plan Pacífico, for the same period (\$256 million). The regional PBP coordinators belong to the Process of Black Communities. For an analysis of the meaning of this project in the strategies of conservationist capital, see Escobar (1996). 
Although it cannot be asserted that biodiversity has become the overriding concern of the movement, it is clear that the movement's construction of a political strategy for the region is increasingly enmeshed with the biodiversity network, and that the PCN itself, in conjunction with PBP and other actors, have created a local/regional site that constitutes a network of its own. The relations among culture, territory, and natural resources constitute a central axis of strategy building both within movement organizations and in their dealings with the state. Conversely, disagreements over views of natural resources have created tensions among community organizations, and between some community sectors and ethnocultural organizations. Many black organizations subordinate ethnocultural principles to state-driven resources for development.

These tensions are related to the overall intensification of development, capitalism, and modernity in the region (A. Escobar and A. Pedrosa 1996). First, the growing migration to the Pacific of peasants, proletarians, and entrepreneurs displaced from the interior of the country is having a visible ecological and social impact arising chiefly from the different cultural logic that these actors bring with them. Second, the government continues to insist on implementing conventional development plans for the region, intended to create infrastructure for the large-scale arrival of capital. Third, government policies for the protection of natural resources have consisted of conventional measures of expansion of natural parks or social forestry programs with little or no community participation. Only the small, but symbolically important, Proyecto Biopacífico has attempted, even if in ambiguous ways, to incorporate the demands of the organized black communities. Finally, the drug cartels have also entered the region in the form of big mining, agroindustrial and tourist projects, with enormous consequences that are still difficult to discern.

It is also necessary to say that the organizational level of the black communities in the central and southern Pacific region is still low. Their vulnerability has been revealed in a variety of cases of environmental conflict between local communities and state, timber, mining, and agroindustrial interests. These conflicts have increased in number and intensity since the approval of Ley 70; in some of them, movement organizations have nevertheless extracted partial but important victories. ${ }^{15}$ These cases have made evident not only the weakness of the state agencies in charge of the protection of natural resources, but the not-infrequent collusion between their functionaries and the private interests exploiting the resources they are supposed to protect. Not infrequenly, state functionaries have allied themselves with local businessmen to repress movement organizations. Often times, local government officials fear facing the severe environmental problems that affect the communities under their jurisdiction. Finally, government measures for the control of environmental abuses are frequently late and inefficient, or induce in the perpetrators only minor corrections to their environmental destructive activities. On the positive side, black

15. Social movement organizations have obtained partial victories in cases such as the following: the suspension of the construction of an oil pipeline ending in the port of Buenaventura; the suspension by the Ministry of the Environment of industrial gold mining in the Buenaventura area; the closing of a hearts-of-palm canning operation in the same area; the reorientation of a reforestation program in the South Pacific region (a particularly important ecological zone with intense timber activity); and the establishment of the von Neumann Institute of Pacific Research. For a discussion of some of these cases and their impact on the movement, see Grueso (1995). 
organizations have been able to use some of these instances of conflict to build interethnic alliances with indigenous movements. ${ }^{16}$ As Martínez Alier (1995) has suggested, the study of environmental conflict and its distributional effects is a central feature of political ecology. To this extent, the Pacific region of Colombia has important lessons for the field.

In this context, PCN activists have developed a political ecology framework that incorporates concepts of territory, biodiversity, life corridors, local economies and territorial governability, and alternative development. They have progressively articulated this framework in their interaction with community, state, NGO, and academic sectors. As already mentioned, the territory is seen as a fundamental and multidimensional space for the creation and recreation of the ecological, economic, and cultural practices of the communities. The defense of the territory is assumed within a historical perspective linking past and future. In the past, communities maintained relative autonomy and forms of knowledge and ways of life conducive to certain uses of natural resources. This relationship between meanings and practices, and the social relations in which they are embedded, is being transformed today by the developmentalist onslaught. Confronted with national and international pressures on the natural and genetic resources of the region, the organized black communities prepare themselves for an unequal and strategic struggle to maintain control over the only remaining territorial space in mainland Colombia over which they still exert a significant cultural and social influence.

The demarcation of collective territories has led activists to develop a conception of the territory that highlights articulations between patterns of settlement, use of spaces, and practices of meanings-uses of resources. This conception is validated by recent anthropological studies that document the cultural models of nature that exist among black river communities. Riverine settlements evidence a longitudinal and discontinuous pattern along the rivers in which multiple economic activities (fishing, agriculture, small-scale mining and forest use, hunting and gathering, subsistence and market activities) are combined and articulated according to the location of the settlement in the upper, medium, or lower segment of the river. This longitudinal dimension articulates with a horizontal axis regulated by the knowledge and use of multiple resources, ranging from those that have been domesticated, close to the river margin (including medicinal herbs and food crops) to the undomesticated species found in the various layers of forest away from the river. A vertical axis (from the infraworld to the supraworld, populated by benevolent or dangerous spirits) also contributes to articulate the patterns of meaning-use of resources. These various axes depend on social relations between communities, which in some parts of the Pacific entail interethnic relations between black and indigenous communities, as well as inter-river social and ecological relations. ${ }^{17}$

16. The construction of alliances with indigenous organizations of the Chocó was especially important in the long negotiations for the creation of the von Neumann Institute of Pacific Research (1996-1997). The Institute, however, fell largely under the control of traditional black politicians of the Chocó. Another important instance of interethnic alliance was the 1995 meeting of indigenous and black organizations of the Pacific to develop a coordinated and combined framework for examining the territory-ethnicityculture relation. See PCN/OREWA (1995) for the proceedings of this meeting. Attempts at interethnic cooperation have continued since, although tensions among black and indigenous groups have also been growing in some areas. 
One of the important contributions of the PBP has been to initiate research and conceptualization of the "traditional production systems" of the river communities. For PBP staff and PCN activists alike, it is clear that these systems are more geared towards local consumption than to the market and accumulation; they have operated as forms of resistance, even if they have also contributed to the region's marginalization. Also commonly appreciated is that traditional practices have been sustainable to the extent that they have enabled the reproduction of the cultural and biophysical ecologies. Among those practices highlighted are the maximal utilization of forest and soil resources; lowintensity exploitation; shifting use of productive space over broad and different ecological areas; manifold and diverse agricultural and extractive activities; family and kindred-based labor practices; and horticulture. Conceived in terms of "adaptive productive sytems," this research has provided useful tools for community and social movement planning and reflection. It is also recognized, finally, that in many of the rivers these systems not only are under heavy stress, chiefly by growing extractivist pressures, but that they are increasingly untenable. It is under these conditions that novel economic and technological strategies are seen as necessary; these strategies should be capable of generating resources for conservation (E. Sánchez and C. Leal 1995).

Activists have introduced other important conceptual innovations, some of which have come about in the process of negotiation with the staff of the biodiversity conservation project. The first one is the definition of "biodiversity" as "territory plus culture." Closely related to it is a view of the entire Pacific rainforest region as a "region-territory of ethnic groups," that is, an ecological and cultural unit that is laboriously constructed through the daily cultural and economic practices of the commmunities. The region-territory is also thought about in terms of "life corridors," veritable modes of articulation between sociocultural forms of use and the natural environment. There are, for instance, life corridors linked to the mangrove ecosystems; to the foothills; to the middle part of the rivers, extending towards the inside of the forest; and those constructed by particular activities, such as traditional gold mining or women's shell collecting in the mangrove areas. Each of these corridors is marked by particular patterns of mobility, social relations (gender, kindred, ethnicity), use of the environment, and links to other corridors; each involves a particular use and management strategy of the territory. In some parts of the region, life corridors rely on interethnic and inter-river relations. ${ }^{18}$

These concepts have been arrived at as much through direct engagement with river communities in the mapping of particular territories as through the engagement with national and transnational events. They allow activists to give content to the basic "territory plus culture" biodiversity equation. The ensuing political ecology is thus based on a complex view of ecocultural dynamics. This complexity is often lacking in government strategies, which divide the territory according to other principles, such as the river basin, overlooking the networks that articulate various rivers together. Conventional approaches also fragment the culturally constructed spatiality represented in particular landscapes, precisely because they are blind to sociocultural dynamics.

17. This extremely brief presentation of a "local model of nature" in the Pacific region is based on an in-depth treatment by Restrepo and del Valle (1996)

18. Both the PBP and the PCN have produced educational, scholarly, ad communications materials on productive systems, river mapping, and local knowledge. 
The region-territory could be said to be a management category of the ethnic groups; but it is more than that. It is a category of interethnic relations that points toward the construction of alternative life and society models. The region-territory is a conceptual unit but also a political project. It entails an attempt to explain biological diversity from inside the eco-cultural logic of the Pacific. The demarcation of collective territories fits into this framework. Government dispositions violate this framework by dividing up the Pacific region among collective territories, natural parks, areas of utilization and areas of sacrifice where megaprojects are to be constructed. The government's development plans, intended to create infrastructure for large-scale capital investment, also militate against conservation. It would be quite difficult to articulate a conservation strategy based on the principles proposed by the PCN with the eco-destructive strategies of national development that prevail in the country.

It is important to point out that the concept of territory is a construction that does not fully emerge out of the long-standing practices of the communities, where rights to land are allocated on a different basis (according to kin, tradition of occupation, etc.). Some observers see the emphasis on collective territories as a mistake of the movement based on a misperception of their strength. However, it is clear that the region-territory is also a result of collective (inter- and intracommunity) ecocultural practices. The territory is seen as the space of effective appropriation of the ecosystem, that is, as those spaces used to satisfy community needs and for social and cultural development. For a given river community, this appropriation has longitudinal and horizontal dimensions, sometimes encompassing several river basins. Thus defined, the territory not only traverses several landscape units, it also embodies a community's life project. The region-territory, on the contrary, is conceived of as a political construction for the defense of the territories and their sustainability. In this way, the region-territory is a strategy of sustainability and viceversa: sustainability is a strategy for the construction and defense of the region-territory. Sustainability must consider cultural processes of signification, biological processes of ecosystem functioning, and technoeconomic processes of resource utilization. Said differently, sustainability cannot be conceived in terms of patches or singular activities, or only oneconomic grounds. It must respond to the integral and multidimensional character of the practices of effective appropriation of ecosystems.

The region-territory thus can be said to articulate the life project of the communities with the political project of the social movement. In sum, the political strategy of the region-territory is essential to strengthening specific territories in their cultural, economic, and ecological dimensions. Current pressures on activists and communities to prepare river-based development and conservation plans entail many contradictions in terms of the existing popular practices. Activists are painfully aware of these contradictions as they embark upon the planning process, and as they try to "buy time" for strategies that respond more closely to local realities and aspirations. ${ }^{19}$

19. This presentation of the political ecology framework developed by the PCN is based chiefly on conversations and in-depth interviews with key PCN activists, particularly Libia Grueso, Carlos Rosero, and Yellen Aguilar (conducted in 1995, 1996, 1997). It is also based on an intensive eight day workshop on river basin ecological design I conducted with Libia Grueso and environmental planner Camila Moreno. The workshop, held in Buevaventura in August 1988, was attended by 25 activists and river community leaders. See also Grueso, Rosero and Escobar (1998). 
Despite these problems, it is undeniable that the PCN vision and political practice is an important contribution to today's intellectual ferment on the nature/society relation in Colombia and elsewhere. Can it be said that it incarnates an alternative biodiversity framework, indeed, a legitimate political ecology? If territory is to be thought of as "the ensemble of projects and representations where a whole series of behaviors and investments can pragmatically emerge, in time and in social, cultural, aesthetic and cognitive space," that is, as an existential space of self-reference where "dissident subjectivities" can emerge (F. Guattari 1995: 23, 24), it is clear that this project is being advanced by the social movements of the Pacific. Similarly, the definition of biodiversity proposed by the movement provides elements for reorienting biodiversity discourses according to local principles of autonomy, knowledge, identity, and economy (V. Shiva 1993). Finally, from the activists' efforts at theorizing local practices of use of resources we learn that "nature" is not an entity "out there" existing outside human history, but that it is deeply produced in conjunction with the collective practice of humans that see themselves as integrally connected to it (P. Descola and G. Pálsson, eds. 1996).

The defense of the territory entails the defense of an intricate pattern of social relations and cultural constructions, and is understood by movement activists in this light. It also implies the creation of a new sense of belonging linked to the political construction of a collective life project and the redefinition of relations with the dominant society. At stake with Ley 70, in this way, is not "land" or even the territory of this or that community but the concept of territoriality itself as a central element in the political construction of reality on the basis of black cultural experience. The struggle for territory is thus a cultural struggle for autonomy and self-determination. This explains why for many people of the Pacific the loss of territory would amount to a return to slavery or, worse perhaps, to becoming "common citizens."

The issue of territory is considered by PCN activists as a challenge to developing local economies and forms of governability that can support its effective defense. The strengthening and transformation of traditional production systems and local markets and economies; the need to press on with the collective titling process; and working towards organizational strengthening and the development of forms of territorial governability are all important components of an overall strategy centered on the region. Despite the fact that the primary interests on the part of the country's conservation establishment (whether state agencies or NGOs) are genetic resources and habitat protection, and not the ecocultural demands of the movement, PCN activists find in biodiversity discussions and programs an important space for struggle that partially converges with the strategies of these actors. Regarding the possibility of slowing down the most predatory activities by capital and the state, biodiversity discussions are of utmost importance for black and indigenous movements.

Finally, local economies and governability bring to the fore the question of development. For the ethnocultural organizations, development must be guided by principles derived from the rights and aspirations of the local communities and must support the affirmation of cultures and the protection of natural environments. These principles include notions of compensation, equity, autonomy, self-determination, affirmation of identity, and sustainability; ${ }^{20}$ they suggest that any development strategy must foster the communities' ethnic identity and decision-making capacity, including their creativity, solidarity, pride in their traditions, consciousness of their rights and forms of knowledge, and attachment to their territory. Any development alternative must articulate a vision of both the present and a possible future based on collective aspirations. It must 
go well beyond the creation of infrastructure and the improvement of material conditions to strengthen local cultures and languages.

PCN activists are by no means dismissive of goals such as health, education, communications, overall economic productivity, and a fair share of public resources. These goals, however, are seen from the perspective of the need to defend the traditional territories and control over them, the rights of the communities to determine planning processes, and the overall goal of cultural and social difference. "Sustainability" is not only an ecological, economic, and technological issue; it involves all of the principles stated above. It reflects the way in which black communities of the Pacific continue to bet on life, peace, and democracy in Colombia sacrificing neither nature nor cultural diversity (PCN 1994). The articulation of the ecological, the cultural, and the economic that underlies this vision constitutes a political ecology for the reconstruction of the relations between nature and society in this part of the world. It also aims at a postdevelopment moment in which the unidimensional character of economistic development is put into question.

It is still too early to evaluate the productivity of the engagement of this particular social movement with the biodiversitydiscourse/network. For many in the national staff of the PBP and for the PCN activists, the shared experience of five years has been hard, tense, and frustrating but generally positive. The PBP and the PCN have shared the goal of "constructing region" in ways that markedly contrast with dominant views. They have developed a more complex view of the Pacific and the socio-economic, cultural and political forces that shape it and have amply demonstrated the lower impact of traditional systems on biodiversity, while debunking the perception that the forest is being destroyed by poor blacks and indians; and they have carried out some concrete projects that have strengthened local organizations. As the first example of persistent and intense negotiation of a development/conservation strategy between the state and a social movement, the experience has provided novel lessons for both sides. For PBP planners, for instance, it was important to learn to go along with the organizational dynamic of community and social movement, so different from that of a project cycle. This was particularly hard to accept for the more scientifically oriented project staff in charge of developing a map of the region's biodiversity. The tension between social science and natural science approaches to biodiversity is as real in the Colombian case as it is elsewhere including the CBD, even if it cannot be reduced to a simple question of disciplinary training. For PCN activists, it was important to come to accept, however provisionally, PBP staff as an ally among the many antagonists facing them, once the initial distrust was overcome. ${ }^{21}$

20. These principles were arrived at in February of 1994 as part of the collective analysis by the PCN of the National Plan for the Development of Black Communities elaborated by the Department of National Planning (DNP). Although there was some black representation in the commission that drafted the plan, including representatives from the PCN, the government rejected the PCN's request to have its own panel of experts and advisors included in the deliberations. As a result, the technocratic vision of the DNP and of conventional black politicians and experts prevailed in the overall conceptualization of the plan. This battle for the first "development plan for black communities" was thus lost by the movement, although not entirely, to the extent that some of its views were included in the Plan. 
Future developments of relevance to biodiversity will be largely shaped by three factors: the question of violence and peace, which is increasingly spilling over into the region from the interior of the country; the ability to imagine and implement alternative development strategies, including conservation, perhaps as a continued effort shared by state and social movements in a transnational context; and the persistence and strength of the movement, significantly weakened and isolated at the end of the 1990s as a result of the distressing social and economic processes taking place in Colombia which have hampered the movement's ability to crystallize a broad organizational base. The current climate in the country is dominated by unprecedented levels of violence coming from many sides (paramilitary and guerrilla groups, the army, and the drug cartels) and by the imposition of a model of accumulation that is proving to be even more exclusionary than those of the past. The opening that has fostered for the first time a discourse that does not see the Pacific region simply as a reservoir of resources to be extracted is at the same time being foreclosed by the brutality and magnitude of the exploitative forces unleashed in recent years and that are enveloping the region day by day as they have every other corner of the nation.

International and scholarly attention to the region might be important in this conjuncture, and I want to end by discussing briefly the potential for a dialogue between academic and social movement political ecologies. This vision of the social movements of the Pacific resonates with current proposals to rethink production as the articulation of ecological, cultural, and technoeconomic productivities (E. Leff 1992, 1995a, 1995b). Leff, in particular, argues for the incorporation of cultural and technological criteria into an alternative production paradigm that goes well beyond the dominant economic rationality. If it is true that sustainability has to be based on the structural and functional properties of particular ecosystems, Leff insists, any alternative production paradigm conducive to sustainability must incorporate the actual, culturally and technologicallyspecific conditions under which nature is appropriated by local actors:

\begin{abstract}
"Sustainable development finds its roots in the conditions of cultural and ecological diversity. These singular and non-reducible processes depend on the functional structures of ecosystems that sustain the production of biotic resources and environmental services; on the energetic efficiency of technological processes; on the symbolic processes and ideological formations underlying the cultural valorization of natural resources; and on the political processes that determine the appropriation of nature" (1995b: 61).
\end{abstract}

Said differently, the construction of alternative production paradigms, political orders, and sustainability are sides of the same process, and this process is advanced in part through the cultural politics of social movements and communities in the defense of their modes of nature/culture. The project of social movements thus constitutes a concrete

21. This brief assessment is based on interviews with PBP staff and PCN activists conducted in the Summer of 1997. By Summer of 1998, it was becoming clear that the project was going to be discontinued, due chiefly to lack of government commitment to providing the funds required as counterpart to the international financing. The general view among staff and activists at that point was that the understanding between both parties came too late, but that the experience has been "very positive" overall. 
expression of the search for alternative production and environmental orders envisioned by political ecologists.

The cultural basis of alternative production is found, in the last instance, in the ensemble of meanings-uses that cultural models underscore. That these meanings-uses also underlie different economic practices has been shown by anthropologists in ways that are quite pertinent for biodiversity discussions. Community economies are grounded in place (even if not place-bound, as they participate in translocal markets), and often rely on holding a commons consisting of land, material resources, knowledge, ancestors, spirits, etc.. Within a Western framework, profits arise from innovations that must thus be protected by intellectual property rights. In many peasant communities, however, innovations emerge within a tradition. By imposing the language of intellectual property rights on peasant systems, the benefits of community innovations are made to accrue to external capital (S. Gudeman and A. Rivera 1990; S. Gudeman 1996).

This is why there is "a need to place innovations and intellectual property rights in a broader context," that of contrasting cultural models. Without saying that intellectual property rights are inappropriate to all situations, it is important to support local knowledge and innovation "not in the hope of securing individual profit but as a way of helping people to protect their commons." This might require protecting "community spaces outside the market so that the place for local innovation is preserved and the results may be locally enjoyed" (S. Gudeman 1996: 118). To foster innovation in local and emergent communities, such as the Colombian Pacific, it is necessary to consider how global knowledge can be positively linked to local practices. This approach is a direct reversal of dominant proposals based on intellectual property rights; it also finds echo in the political ecology articulated by social movements. As Martínez Alier (1996) put it, the conflict between economic-chrematistic reasoning and ecological reasoning that is central to biodiversity debates today needs to be solved politically. Otherwise, conservation strategies will amount to a merchandising of biodiversity. Is it possible to defend a posteconomistic, ecological production rationality? It seems that social movements are the clearest advocates of ecological economics in practice. At least they refuse to reduce territorial and ecological claims to the exclusive terms of the market, and this is an important lesson for any biodiversity conservation strategy (S. Varese 1996).

\section{Conclusion}

I have argued in this paper for a view of biodiversity as a construction constituting a powerful interface between nature and culture and originating a vast network of sites and actors through which concepts, policies, and ultimately cultures and ecologies are contested and negotiated. This construction has a growing presence in the strategies of social movements in many parts of the world. The social movement of black communities of the Colombian Pacific region, for instance, enacts a cultural politics that is significantly mediated by ecological concerns, including biodiversity. Despite the negative forces opposing it, and in the climate of certain favorable ecological and cultural conjunctures, it is not impossible to think that this movement might represent a real defense of the social and biophysical landscapes of the region. This defense advances through a slow and laborious construction of Afro-Colombian identities that articulate with alternative constructions of development, territory, and biodiversity conservation. The social movement of black communities can thus be described as one of cultural and ecological attachment to a territory, even as an attempt at creating new existential territories. Despite 
its precariousness, its articulation of a link between culture, nature, and development constitutes an alternative political ecology framework for biodiversity discussions. The movement can be seen as an attempt to show that social life, work, nature, and culture can be organized differently than dominant models of culture and the economy mandate.

This political ecology is validated by recent trends in academic anthropology and political ecology. Its approach to biodiversity conservation from the perspective of the ecocultural construction of the region-territory can be seen in terms of the defense of local models of nature documented by ecological anthropologists; the practice models of economic anthropology and the anthropology of local knowledge; and the alternative production rationality articulated by political ecologists. Conversely, such academic concepts can be further refined through reflection on the political practice of social movements. There is scope for a mutually beneficial dialogue between academic and social movement activists interested in conservation and other environmental matters. As anthropologists and others are beginning to demonstrate with greater eloquence, issues of conservation, compensation, and use of biodiverse resources are not only more complex than dominant views suggest, but they lend themselves to creative thinking and policymaking alternatives (S. Brush and D. Stabinsky, eds. 1996). It is time for us to take on this challenge in full earnest with a variety of social actors, from social movements to progressive academics and NGOs.

One thing is certain: the distance between dominant discourses of biodiversity conservation and the political ecology of social movements is great and perhaps growing. One would hope nevertheless that in the spaces of encounter and debate provided by the biodiversity network there could be found ways for academics, scientists, NGOs and intellectuals to reflect seriously on, and support, the alternative frameworks that, with a greater or lesser degree of explicitness and sophistication, Third World social movements are crafting. Then we could address in a more grounded way the question posed at the beginning: Can the world be redefined and reconstructed from the perspective of the multiple cultural and ecological practices that continue to exist among many communities? This is above all a political question, but one that entails serious epistemological, cultural, and ecological considerations.

\section{References Cited}

Alvarez, Sonia, Evelina Dagnino and Arturo Escobar, editors.

1998. Cultures of Politics/Politics of Cultures. Re-visioning Latin American Social Movements. Boulder: Westview Press.

Aprile-Gniset, Jacques.

1993. Poblamiento, Hábitats y Pueblos del Pacífico. Cali: Universidad del Valle.

Asher, Kiran.

1998. "The Politics of Gender and Ethnicity in the Pacific Coast of Colombia." PhD dissertation, Department of Political Science, University of Florida at Gainesvlle.

Balick, Michael, Elaine Elisabetsky and Sarah Laird, editors.

1996. Medicinal Resources of the Tropical Forests. New York: Columbia University Press.

Baskin, Yvonne.

1997. The Work of Nature. How the Diversity of Life Sustains Us. Washington, DC: Island Press. 
Brush, Stephen, 1998. "Prospecting the Public Domain." Presented at the Globalization Project, Center for Latin American Studies, University of Chicago, February 12.

Brush, Stephen, and Doreen Stabinsky, editors. 1996. Valuing Local Knowlege. Washington: Island Press.

Callon, Michel.

1986. "The Sociology of an Actor-Network: The Case of the Electric Vehicle." In Mapping the Dynamics of Science and Technology. M. Callon, et al, editors. London: McMillan.

Camacho, Juana.

1996. "Black Women and Biodiversity in the Tribugá Golf, Chocó, Colombia." Final report presented to the MacArthur Foundation, Bogotá.

Dahl, Gudrun, editor.

1993. Green Arguments for Local Subsistence. Stockholm: Stockholm Studies in Social Anthropology.

Descola, Philippe, and Gísli Pálsson, editors.

1996. Nature and Society. Anthropological Perspectives. London: Routledge.

Escobar, Arturo.

1999. "After Nature: Steps to an Anti-essentialist Political Ecology." Current Anthropology 40(1):1-30.

Escobar, Arturo.

1998. "Gender, Place and Networks. A Political Ecology of Cyberculture." In Wendy Harcourt, editor. Women@ Internet: Creating New Cultures in Cyberspace. London: Zed Books pp.31-54.

Escobar, Arturo.

1997a. "Biodiversidad, Naturaleza y Cultura: Localidad y Globalidad en las Estrategias de Conservación." Colección El Mundo Actual. Méxco, D.F.: UNAM/ CIICH.

Escobar, Arturo.

1997b. "Cultural Politics and Biological Diversity: State, Capital and Social Movements in the Pacific Coast of Colombia." In Between Resistance and Revolution. R. Fox and O. Starn, editors. New Brunswick: Rutgers University Press, pp. 40-64.

Escobar, Arturo.

1996. "Constructing Nature: Elements for a Post-structuralist Political Ecology." In

Liberation Ecologies. R. Peet and M. Watts, editors. London: Routledge, pp. 46-68. Escobar, Arturo.

1995. Encountering Development. Princeton: Princeton University Press.

Escobar, Arturo, and Alvaro Pedrosa, editors.

1996. Pacífico: Desarrollo o Diversidad? Estado, Capital y Movimientos Sociales en

el Pacífico Colombiano. Bogotá: CEREC/Ecofondo.

Ferguson, James.

1990. The Ant-Politics Machine. Cambridge: Cambridge University Press.

Foucault, Michel.

1980. The History of Sexuality. Volume I. New York: Pantheon Books.

Friedemann, Nina S. de, and Jaime Arocha, editors.

1984. Un Siglo de Investigación Social en Colombia. Bogotá: Etno.

GEF/PNUD (Global Environment Facility/United Nations Development Program). 
1993. Conservación de la Biodiversidad del Chocó Biogeográfico. Proyecto Biopacífico. Bogotá: DNP/Biopacífico.

GRAIN (Genetic Resources Actions International).

1998. "Patenting Life: Progress or Piracy?." Global Biodiversity 7(4): 2-6.

Grueso, Libia.

1995. "Diagnósticos, Propuestas y Perspectivas de la Región del Chocó Biogeográfico en Relación con la Conservación y Uso Sostenido de la Biodiversidad." Unpublished report to Proyecto Biopacífico, Bogotá.

Grueso, Libia, Carlos Rosero and Arturo Escobar.

1998. "The Process of Black Community Organizing in the Southern Pacific Coast of Colombia." In Cultures of Politics/Politics of Cultures: re-visioning Latin American Social Movements. S.E. Alvarez, E. Dagnino and A. Escobar, editors. Boulder: Westview Press, pp. 196-219.

Guattari, Félix. 1995. Chaosophy. New York: Semiotext[e].

Gudeman, Stephen.

1996. "Sketches, Qualms, and Other Thoughts on Intellectual Property Rights." In Valuing Local Knowledge. S. Brush and Doreen Stabinsky, editors. Washington, D.C.: Island Press, pp. 102-121.

Gudeman, Stephen, and Alberto Rivera.

1990. Conversations in Colombia. The Domestic Economy in Life and Text. Cambridge:Cambridge University Press.

Hall, Stuart.

1990. "Cultural Identity and Diaspora." In Identity, Community, Culture, Difference.

J. Rutherford, editor. London: Lawrence and Wishart, pp. 392-403.

Hess, David.

1997. Science Studies. An Advanced Introduction. New York: New York University Press.

Hobart, Mark.

1993. "Introduction: The Growth of Ignorance?" In An Anthropological Critique of Development. The Growth of Ignorance. M. Hobart, editor. London: Routledge, pp. 1-30.

Hvalkof, Soren.

1998. "Outrage in Rubber and Oil. Extractivism, Indigenous Peoples and Justice in the Upper Amazon." In Peoples, Plants and Justice: Resource Extraction and Conservation in Tropical Developing Countries. Charles Zerner, editor. New York: Columbia University Press, pp. 425-450.

Ingold, Tim.

1995. "Building, dwelling, living: how animals and people make themselves at home in the world." In Shifting Contexts. Tranformations in Anthropological Knowledge. M. Strathern, editor. London: Routledge, pp. 57-80.

Ingold, Tim.

1996. "The Optimal Forager and Economic Man." In Nature and Society. P. Descola and G. Pálsson, editors. London: Routledge, pp. 25-44.

Janzen, Daniel.

1992. "A South-North Perspective on Science in the Management, Use and Economic Development of Biodiversity." In Conservation of Biodiversity for Sustainable 
Development. O.T. Sanlund, K. Hindar and A.H.D. Brown, editors. Oslo: Scandinavian University Press.

Janzen, Daniel, and H. Hallwachs.

1993. All Taxa Biodiversity Inventory. Philadelphia: University of Pennsylvania (downloaded from Internet).

King, Stephen, Thomas Carlson and Katy Moran.

1996. "Biological Diversity, Indigenous Knowledge, Drug Discovery, and Intellectual Property Rights." In Valuing Local Knowledge. S. King and D. Stabinsky, editors. Washington: Island Press, pp. 167-185.

Latour, Bruno.

1993. We Have Never Been Modern. Cambridge: Harvard University Press.

Latour, Bruno.

1983. "Give me a Laboratory and I will Raise a World." In Science Observed. K.

Knorr-Cetina and M. Mulkay, editors. London: Sage, pp. 141-170.

Leff, Enrique.

1992. "La Dimensión Cultural y el Manejo Integrado, Sustentable y Sostenido de los Recursos Naturales." In Cultura y Manejo Sustentable de los Recursos Naturales. E. Leff and J. Carabias, editors. México, D.F.: CIICH/UNAM.

Leff, Enrique.

1995a. Green Production. Toward and Environmental Rationality. New York: Guilford Press.

Leff, Enrique.

1995b. "De quién es la naturaleza? Sobre la reapropriación social de los recursos naturales." Gaceta Ecológica 37: 58-64.

Leff, Enrique.

1997. "Epistemología Política, Apropiación de Saberes Etnobotánicos y Manejo Sustentable de la Diversidad Vegetal." Presented at the Second International Congress of Ethnobotany, Mérida, México, 16-17 October.

Leyva, Pablo, editor. 1993. Colombia Pacífico. Bogotá: Fondo FEN.

Lozano, Betty Ruth. 1996. "Mujer y Desarrollo." In Pacífico: Desarrollo o Biodiversidad?. A. Escobar and A. Pedrosa, editors. Bogotá: CEREC/Ecofondo, pp. 176-204

Mackay, David.

1996. "Agents of Empire: The Banksian Collectors and Evaluation of New Lands." In Visions of Empire: Voyages, Botany, and Representations of Nature. D. Miller and P.H. Reill, editors. Cambridge: Cambridge University Press.

Martínez Alier, Joan.

1995. "Political Ecology, Distributional Conflicts, and Ecological Incommesurability." New Left Review 211: 70-88.

Martínez Alier, Joan.

1996. "Merchandising Biodiversity." Capitalism, Nature, Socialism 7(1): 37-54.

McAfee, Kathy.

1997. "Selling Nature to Save it? Biodiversity and the Rise of Green Developmentalism." Inaugural International Conference of Critical Geography. Vancouver, BC, August 13.

Melucci, Alberto.

1989. Nomads of the Present. Philadephia: Temple University Press. 
Miller, David, and P.H. Reill, editors.

1996. Visions of Empire: Voyages, Botany, and Representations of Nature. Cambridge: Cambridge University Press.

Milton, Kay.

1996. Environmentalism and Cultural Theory. London: Routledge.

Mooney, H.A, J. Lubchenko, R. Dirzo and O.E. Sala, eds.

1995. "Biodiversity and Ecosystem Functioning." In Global Biodiversity Assessment. United Nations Environment Program, ed. Cambridge: Cambridge University Press, pp. 275-452.

Moran, Katy.

1997. "Past as Prologue: Issues on Bridging the Traditional and Modern Worlds." In Building Bridges with Traditional Knowledge. A. Paul, D. Wigston and C. Peters, editors. New York: New York Botanical Gardens Press.

Norgaard, Richard.

1995. Development Betrayed. London: Routledge.

PCN (Proceso de Comunidades Negras).

1994. Documento para Discusión Frente al Plan Nacional de Desarrollo para Comunidades Negras. Unpublished manuscript.

PCN (Proceso de Comunidades Negras) and OREWA (Organización Regional EmberaWaunana).

1995. Territorio, Etnia, Cultura e Investigación en el Pacífico Colombiano. Cali: Fundación Habla/Scribe.

Third World Network and Research Foundation for Science, Technology and Natural

Research Policy.

1994. Resource Kit for Building a Movement for the Protection of Biodiversity and People's Intellectual Rights. Kuala Lampur/Dehra Dun: Third World Network and Research Foundation.

Restrepo, Eduardo, and Jorge I. del Valle, editors.

1996. Renacientes del Guandal. Bogotá: Proyecto Biopacífico/Universidad Nacional.

Ribeiro, Gustavo Lins.

1997. "Transnational Virtual Community? Exploring Implications for Culture, Power and Language." Organization 4(4): 496-505.

Richards, Paul.

1993. "Cultivation: Knowledge or Performance?." In An Anthropological Critique of Development. M. Hobart, editor. London: Routledge, pp. 61-78.

Rojas, Jeannette.

1996. "Las Mujeres en Movimiento. Crónicas de Otras Miradas." In Pacífico:

Desarrollo o Diversidad?. A. Escobar and A. Pedrosa, editors. Bogotá: CEREC/ Ecofondo, pp. 205-219.

Sánchez, Enrique, and Claudia Leal.

1995. "Elementos para una Evaluación de Sistemas Productivos Adaptativos en el Pacífico Colombiano." In Economías de las Comunides Rurales en el Pacífico Colombiano. C. Leal, editor. Bogotá: Proyecto Biopacífico, pp. 73-88.

Shiva, Vandana.

1993. Monocultures of the Mind. London: ZED Books.

Shiva, Vandana.

1997. Biopiracy. Boston: South End Press.

Shiva, Vandana, editor. 
1994. Close to Home. Women Reconnect Ecology, Health and Development Worldwide. London: Zed Books.

Shiva, Vandana, Patrick Anderson, Heffa Schucking, Andrew Gray, Larry Lohmann, and David Cooper.

1991. Biodiversity: Social and Ecological Perspectives. London: Zed Books.

Strathern, Marilyn.

1980. "No Nature, No Culture: The Hagen Case." In Nature, Culture and Gender. C. MacCormack and M. Strathern, editors. Cambridge: Cambridge University Press, pp.174-222.

Takacs, David.

1996. The Idea of Biodiversity. Baltimore: Johns Hopkins University Press.

Varese, Stefano.

1996. "The New Envirommentalist Movement of Latin American Indigenous People." In Valuing Local Knowledge. S. Brush and D. Stabinsky, editors. Washington, DC: Island Press, pp. 122-142.

Wade, Peter.

1995. "The Cultural Politics of Blackness in Colombia." American Ethnologist 22(2): 341-357.

Whitten, Norman.

1986. Black Frontiersmen: Afro-Hispanic Culture of Ecuador and Colombia. Prospect Heights, Ill: Waveland Press.

Wilson, Edward.

1993. The Diversity of Life. New York: W.W. Norton.

World Resources Institute (WRI).

1995. National Biodiversity Planning. Washington, DC: WRI.

World Resources Institute.

1994. World Resources, 1994-95. Washington, D.C.: WRI.

World Resources Institute.

1993. Biodiversity Prospecting. Oxford: Oxford University Press.

WRI/IUCN/UNEP.

1992. Global Biodiversity Strategy.

\section{Abstract}

This paper proposes a framework for rethinking the conservation and appropriation of biological diversity from the perspective of social movements. It argues that biodiversity, although with concrete biophysical referents, is a discourse of recent origin. This discourse fosters a complex network of diverse actors, from international organizations and NGOs to local communities and social movements. Four views of biodiversity produced by this network (centered on global resource management, national sovereignity, biodemocracy, and cultural autonomy, respectively) are discussed in the first part of the paper. The second part focuses on the cultural autonomy perspective developed by social movements. It examines in detail the rise and development of the social movement of black communities in the Pacific rainforest region of Colombia. This movement, it is argued, articulates through their practice an entire political ecology of sustainability and conservation. The main elements of this political ecology are discussed and presented as a viable alternative to dominant frameworks. 
Key words: political ecology, social movements, rainforest, biodiversity, afrocolombians, global networks.

\section{Resumé}

Ce document propsoses un cadre conceptuel pour repenser la question de l'appropriation et de la conservation de la diversité biologique du point de vue des mouvements sociaux. Bien que les referents de la biodiversité aient une fondation concrete ancienne, le discours en lui-meme est d'origine récente.Ce discours recèle un certain nombre d'acteurs allant d'organisation non gouvernementales ou internationales, de communautés locales et d'organisations sociales. Quatre grandes perspectives (centrées respectivement autour de la gestion de ressources globales, de la souveraineté, de la biodiversité, et de l'autonomie culturelle)sont exposées dans la première partie du document. La seconde partie du texte met l'accent sur la perspective autonomiste developpée par les mouvements sociaux. L'auteur explore en details la montée et le developpement des mouvements sociaux des communautés noires vivant la region Pacifique de la forêt equatoriale Colombienne. Un argument est avancé selon lequel ce mouvement s'articule autour d'une pratique écologique globale mettant en avant-garde le caractere soutenu et perrain du système. Les principales composantes de cette théorie sont présentées comme une alternative viable paradigmes dominants.

Mots clefs: politico-écologique, mouvements sociaux, forêt equatoriale, diversité biologique, afrocolombiens, reseaux globaux.

\section{Resumen}

Este artículo propone un marco analítico para la reconsideración de la conservación y la apropriación de la diversidad biológica desde la prespectiva de movimientos sociales. Se arguye que la diversidad biológica aunque con referentes biofisicas concretos, es un discurso de origin reciente. Este discurso promueve una red compleja de actores diversos, desde organizaciones internacionales y ONGs hasta comunidades locales y movimientos sociales. Cuarto perspectivas de la diversidad biológica producidas por esta red (central en el manejo de recursos globales, soberanía nacional, bio-democracia, y autonomía cultural respectivamente) son discutidos en la primera parte de este articulo. La secunda parte se enfoca en la perspectiva de autonomía cultural de movimientos sociales. Se examina en detalle el crecimiento y desarrollo del movimiento social de comundiades negras de la región de la selva lluviosa del Pacífico de Colombia. Esta moviemento articula a traves de su práctica , una ecología política completa basada de la conservación y la sostenilidad. Los elementos principales de esta ecología política son discutidos y presentados como una alternativa viable al los marcos dominantes.

Palabres claves: ecología política, movimientos sociales, selva lluviosa, diversidad biológica, afrocolombianos, redes globales 